BUDGETING : Journal of Business, Management and Accounting

Volume 2, Nomor 1, Desember 2020

e-ISSN: 2715-2480

p-ISSN: 2715-1913

DOI : https://doi.org/10.31539/budgeting.v2i1.1737

\title{
PENENTUAN HARGA JUAL BATIK BERDASARKAN HARGA POKOK PRODUKSI MENGGUNAKAN METODE VARIABLE COSTING
}

\author{
Bela Anggardini ${ }^{1}$, Dwi Cahyono ${ }^{2}$, Achmad Syahfrudin ${ }^{3}$ \\ Universitas Muhammadiyah Jember ${ }^{1,2,3}$ \\ belaadini@gmail.com ${ }^{1}$
}

\begin{abstract}
ABSTRAK
Tujuan penelitian ini adalah untuk mengetahui perbedaan perhitungan antara harga pokok produksi perusahaan UD. Batik Redj'os selama ini dengan perhitungan menggunakan metode variabel costing dan pengaruhnya terhadap laba yang akan diperoleh oleh perusahaan. Metode analisis yang digunakan adalah analisis deskriptif. Hasil penelitian menunjukkan bahwa perhitungan harga pokok produksi pesanan perusahaan dengan perhitungan menggunakan metode variabel costing memiliki selisih. Selisih tersebut disebabkan karena perusahaan belum menentukan dasar tarif pembebanan biaya overhead pabrik dan perusahaan juga belum membebankan biaya listrik dan telepon ke dalam harga pokok pesanan. Menurut perusahaan harga pokok pesanan lebih kecil dibandingkan dengan perhitungan menggunakan metode variable costing baik pada produk batik cap maupun batik tulis. Simpulan, perhitungan harga pokok produksi pada UD. Batik Redj'os belum sesuai dengan perhitungan harga pokok produksi yang sebenarnya menurut akuntansi yang benar. Adapun dalam menentukan biaya overhead pabrik, perhitungan yang dilakukan perusahaan masih kurang tepat. Jumlah harga pokok pesanan kain batik cap ataupun kain batik tulis berdasarkan perhitungan metode variable costing lebih besar dari perhitungan perusahaan.
\end{abstract}

Kata Kunci: Harga Pokok Produksi, Metode Variabel Costing

\section{ABSTRACT}

The purpose of this study was to determine the difference in the calculation between the cost of goods manufactured by UD company. Batik Redj'os has been calculated using the variable costing method and its effect on profits to be obtained by the company. The analytical method used is descriptive analysis. The results showed that the calculation of the cost of goods manufactured by company orders using the variable costing method has a difference. The difference is due to the fact that the company has not yet determined the base rate for charging factory overhead costs and the company has not yet charged electricity and telephone costs to the cost of the order. According to the company, the cost of the order is smaller than the calculation using the variable costing method for both printed and written batik products. Conclusion, the calculation of the cost of production at UD. Batik Redj'os is not in accordance with the actual calculation of the cost of goods manufactured according to correct accounting. As for determining factory overhead costs, the calculations made by the company are still inaccurate. The total cost of the printed batik cloth or written batik cloth based on the variable costing method calculation is greater than the company calculation.

Keywords: Cost of Production, Variable Costing Method 


\section{PENDAHULUAN}

Usaha Kecil dan Menengah (UKM) di berbagai negara termasuk di Indonesia merupakan salah satu penggerak perekonomian rakyat yang tangguh. Hal ini karena kebanyakan para pengusaha kecil dan menengah bergerak dari industri keluarga atau rumahan. Para konsumen juga berasal dari kalangan menengah hingga ke bawah. Selain itu peranan UKM terutama sejak krisis moneter tahun 1998 dapat dipandang sebagai katup penyelamat dalam proses pemulihan ekonomi nasional, baik dalam mendorong laju pertumbuhan ekonomi maupun penyerapan tenaga kerja (Rudjito, 2003).

Permasalahan yang muncul dalam UKM adalah mengenai laporan tentang biaya yang dikeluarkan selama proses produksi dalam suatu periode. Untuk memperoleh informasi biaya produksi tersebut dibutuhkan pengolahan data sesuai teori serta prinsip akuntansi, sehingga dapat digunakan dalam menentukan Harga Pokok Produksi (HPP) yang tepat. Menurut Firdaus \& Wasilah (2012) penentuan HPP menjadi hal yang sangat penting karena dapat menjadi hal yang menentukan pendapatan para pelaku UKM dan berkaitan dengan laba yang akan diperoleh perusahaan.

Komponen pembentukan laba adalah pendapatan yang diperoleh dari hasil penjualan produksi dan jasa yang dihasilkan oleh perusahaan. Adapun biaya adalah pengorbanan yang harus dikeluarkan oleh perusahaan untuk memproduksi atau menghasilkan suatu barang dan jasa. Biaya tersebut disebut sebagai biaya harga pokok atau harga pokok atau HPP (Riwayadi, 2016).

Penentuan besarnya biaya yang dikeluarkan harus tepat dan akurat sehingga biaya-biaya yang ada atau dikeluarkan dalam proses produksi akan menunjukkan harga pokok sesungguhnya. Penentuan HPP merupakan hal yang sangat penting mengingat manfaat informasi HPP adalah untuk menentukan harga jual produk serta pentuan harga pokok persediaan produk jadi dan produk dalam proses yang akan disajikan dalam neraca. Harga jual yang terlalu tinggi akan menjadikan produk kurang bersaing di pasar, sementara harga jual yang terlalu rendah tidak memberikan keuntungan bagi pengusaha.

Penentuan HPP menjadi masalah yang harus diperhatikan oleh UKM untuk memberikan penentuan harga jual yang tepat hingga dapat menghasilkan laba yang optimal. HPP sangat menentukan laba rugi perusahaan. Penelitian yang dilakukan oleh Elvania (2017) tentang penentuan HPP menggunakan metode variable costing guna penentuan harga jual produk tahu takwa pada Usaha Bintang Barokah Kediri 
menunjukkan bahwa perhitungan harga pokok produksi sebagai dasar penetapan harga jual yang dilakukan oleh Usaha Bintang Barokah Kediri masih sangat sederhana. Biaya yang dihitung sebagai biaya produksi meliputi biaya bahan baku, biaya tenaga kerja langsung dan biaya overhead pabrik. Dalam melakukan proses produksi tidak semua biaya overhead pabrik diperhitungkan.

Perhitungan harga pokok produksi dengan menggunakan metode variable costing pada Usaha Bintang Barokah Kediri dilakukan dengan menghitung seluruh biaya yang dikeluarkan dalam proses produksi tahu takwa. Harga jual yang diperoleh menggunakan metode variable costing dan pendekatan cost-plus pricing dengan keuntungan sebesar 30\% atau Rp1.648,00. Perhitungan harga pokok produksi menggunakan metode variable costing menghasilkan harga jual yang lebih tinggi dibandingkan dengan metode yang ditetapkan oleh perusahaan. Perbedaan selisih harga jual produk adalah sebesar Rp. 184. Jumlah tahu takwa yang diproduksi Usaha Bintang Barokah Kediri selama tahun 2016 adalah sebanyak 892.000 unit, maka jumlah selisih harga jual sebesar Rp191.952.000,00.

Berdasarkan hasil survey di salah satu UKM yaitu UD. Batik Redj'os (perusahaan pembuat batik di Kota Lumajang), selama ini perusahaan hanya menghitung harga pokok produk berdasarkan pesanan dengan cara menjumlahkan biaya bahan baku, biaya tenaga kerja serta biaya overhead pabrik. Namun biaya overhead pabrik yang dihitung hanya berdasarkan perkiraan pemakaian bahan penolong saja. UD. Batik Redj'os tidak memasukkan biaya telepon, biaya listrik dan biaya air kedalam biaya overhead pabrik.

Perlakuan biaya overhead pabrik yang tidak tepat akan menyebabkan ketidaktepatan dalam menentukan harga pokok produksi yang dihasilkan. Maka dari itu perlu dilakukan evaluasi pada hal tersebut agar dapat digunakan dalam pengambilan berbagai keputusan nantinya. Di sisi lain penentuan harga pokok yang wajar akan dapat digunakan dalam penentuan laba rugi perusahaan, sehingga dapat mencerminkan laba yang sesungguhnya yang menjadi tujuan UD. Batik Redj'os. Berdasarkan hal-hal tersebut, maka peneliti tertarik untuk melakukan analisis pada UD. Batik Redj'os Kabupaten Lumajang mengenai HPP batik dengan menggunakan metode variable costing guna menentukan harga jual yang tepat. 


\section{KAJIAN TEORI}

Biaya

Pemahaman mengenai biaya sangat penting untuk dimiliki karena penerapan biaya yang tepat dapat digunakan untuk membantu proses perencanaan, pengendalian dan pembuatan keputusan ekonomi. Terdapat berbagai macam pengertian atau definisi biaya yang masing-masing berbeda. Oleh karena itu sangat penting untuk menyadari sepenuhnya arti biaya tersebut dalam menjalankan tujuan sehari-hari (Shepherd \& Martin, 2018).

\section{Obyek Biaya}

Menurut Carter (2013) suatu objek biaya (cost object) atau tujuan biaya (cost objective) didefinisikan sebagai suatu item atau aktivitas yang biayanya diakumulasi dan diukur. Menurut Riwayadi (2014) pada dasarnya obyek biaya adalah kegiatan atau aktivitas yang memerlukan adanya pengukuran atau penentuan biayanya secara tersendiri. Dengan kata lain, jika pemakai informasi akuntansi ingin mengetahui berapa besarnya biaya untuk sesuatu (mengukur), maka sesuatu itu disebut obyek biaya.

\section{Penggolongan Biaya}

Menurut Mulyadi (2007) ada beberapa penggolongan biaya yang sering dilakukan, antara lain: 1) penggolongan biaya menurut hubungan sesuatu yang dibiayai, yang terdiri dari biaya langsung (direct cost) dan biaya tidak langsung (indirect cost); 2) penggolongan biaya atas dasar fungsi pokok dalam perusahaan yang terdiri dari biaya produksi, biaya pemasaran, biaya administrasi dan umum; 3) penggolongan biaya menurut perilaku dalam hubungannya dengan perubahan volume kegiatan yang terdiri dari biaya tetap (fixed cost), biaya variabel (variable cost) dan biaya semi variabel.

\section{Harga Pokok Produksi}

Menurut Mulyadi (2009) Harga Pokok Produksi (HPP) merupakan elemen penting untuk menilai keberhasilan atau mencapai keuntungan dari perusahaan maupun manufaktur. HPP mempunyai kaitan erat dengan indikator-indikator tentang suksesnya suatu perusahaan, seperti laba kotor penjualannya dan laba bersihnya, tergantung pada 
rasio antara harga jual dan harga pokok produknya. Perubahan HPP yang relatif kecil dapat berdampak signifikan pada indikator keberhasilannya.

Manfaat informasi HPP adalah sebagai berikut: 1) menentukan harga jual produk; 2) memantau realisasi biaya produksi; 3) menghitung laba rugi periodik; 4) menentukan harga pokok. Menurut Supriyono (2013) unsur-unsur HPP mencakup tiga hal, yaitu: 1) biaya bahan baku; 2) biaya tenaga kerja langsung; 3) biaya overhead pabrik.

\section{Tarif BOP}

Menurut Mulyadi (2012) biaya overhead pabrik yang sesungguhnya terjadi merupakan biaya yang dikumpulkan selama satu tahun yang sama, kemudian pada akhir tahun dibandingkan dengan yang dibebankan kepada produk atas dasar tarif. Perusahaan yang produksinya berdasarkan pesanan, biaya overhead pabrik dibebankan kepada produk atas dasar tarif yang ditentukan di muka.

Terdapat dua metode dalam penentuan HPP yaitu metode full costing dan metode variable costing. Adapun untuk menentukan harga jual terdiri dari tiga metode yaitu penentuan harga jual normal (normal pricing), penentuan harga jual dalam costtype contract, gross margin pricing dan penentuan harga jual berdasarkan laba yang ditargetkan.

\section{METODE PENELITIAN}

Pengumpulan data pada penelitian ini dilakukan dengan mengumpulkan data di lokasi penelitian dengan melakukan observasi, wawancara dan dokumentasi untuk menentukan strategi pengumpulan data yang dipandang tepat dan untuk menentukan fokus serta pendalaman data proses pengumpulan data berikutnya. pembebanan tarif biaya overhead pabrik dilakukan berdasarkan pesanan, maka dalam pembebanan biaya overhead pabrik menggunakan dasar tarif BOP yang ditentukan di muka.

Perhitungan harga pokok pesanan dilakukan dengan pendekatan variable costing. Kemudian dilakukan penarikan kesimpulan sebagai hasil analisis yang dapat digunakan untuk mengambil tindakan. Teknik analisis data yang digunakan dalam penelitian ini adalah metode deskriptif kualitatif. Dengan metode ini data yang diperoleh dianalisa secara kualitatif, yaitu dengan mengkaji, memaparkan, menelaah 
dan menjelaskan data-data yang diperoleh pada UD. Batik Redj'os Kecamatan Rowokangkung, Kabupaten Lumajang.

\section{HASIL PENELITIAN}

\section{Jenis Produksi}

Fokus penelitian ini hanya pada pesanan kain batik cap dan kain batik tulis. Peneliti mengambil dua produk tersebut karena sering dipesan oleh konsumen. Data yang diambil adalah harga pokok pesanan yang ada di bulan Mei tahun 2018. Berikut ini adalah data produk pesanan kain batik pada bulan Mei:

Tabel 1.

Data Produk Pesanan UD. Batik Redj'os pada Bulan Mei 2018

\begin{tabular}{cccc}
\hline No. & \multicolumn{1}{c}{ Nama Pesanan } & Jenis Pesanan & Jumlah Pesanan (/ Potong) \\
\hline 1 & KPRI GURU Kec.Rowokangkung & Kain Batik Cap & 100 \\
2 & Kepala Desa Sidorejo & Kain Batik Tulis & 40 \\
\hline \multicolumn{2}{c}{ Jumlah } & & 140 \\
\hline
\end{tabular}

(Sumber: UD. Batik Redj'os)

\section{Analisis Data}

\section{Biaya Produksi}

Besarnya biaya produksi kain batik yang dikeluarkan oleh UD. Batik Redj'os pada Bulan Mei 2018 adalah sebagai berikut:

Tabel 2.

Biaya Bahan Baku UD. Batik Redj'os Pesanan Batik Cap 100 Potong

\begin{tabular}{cccc}
\hline Jenis & Kuantitas & Harga Satuan (Rp) & Jumlah (Rp) \\
\hline Kain Mori (Prima) & $200 \mathrm{~m}$ & $20.000,00$ & $4.000 .000,00$ \\
\hline & Jumlah & & $4.000 .000,00$ \\
\hline
\end{tabular}

(Sumber: UD. Batik Redj'os)

Tabel 3.

Biaya Bahan Baku UD. Batik Redj'os Pesanan Batik Tulis 40 Potong

\begin{tabular}{cccc}
\hline Jenis & Kuantitas & Harga Satuan (Rp) & Jumlah (Rp) \\
\hline Kain Mori (Primissima) & $80 \mathrm{~m}$ & $25.000,00$ & $2.000 .000,00$ \\
\hline & Jumlah & & $2.000 .000,00$ \\
\hline
\end{tabular}

(Sumber: UD. Batik Redj'os) 
Tabel 4.

Biaya Tenaga Kerja Langsung

Pesanan Kain Batik Cap 100 Potong

\begin{tabular}{cccc}
\hline No & Jenis Produk & Jenis Pekerjaan & Biaya Tenaga Kerja Langsung (Rp) \\
\hline 1 & & Mencap & $75.000,00$ \\
2 & & Nyolet & $875.000,00$ \\
3 & Kain Batik Cap & Dasarin & $875.000,00$ \\
4 & & Penguncian & $50.000,00$ \\
5 & & Nglorot & $60.000,00$ \\
6 & & Packing (setrika) & $30.000,00$ \\
\hline & & & $1.965 .000,00$ \\
\hline
\end{tabular}

(Sumber: Data Diolah)

Tabel 5.

Biaya Tenaga Kerja Langsung

Pesanan Kain Batik Tulis 40 Potong

\begin{tabular}{cccc}
\hline No & Jenis Produk & Jenis Pekerjaan & Biaya Tenaga Kerja Langsung (Rp) \\
\hline 1 & & Gambar & $80.000,00$ \\
2 & Nyanting & $1.080 .000,00$ \\
3 & & Nyolet & $400.000,00$ \\
4 & Kain Batik Tulis & Dasarin & $400.000,00$ \\
5 & & Penguncian & $50.000,00$ \\
6 & & Nglorot & $60.000,00$ \\
7 & & Packing (setrika) & $15.000,00$ \\
\hline & & & $2.085 .000,00$ \\
\hline
\end{tabular}

(Sumber: Data Diolah)

\section{Biaya Overhead Pabrik}

Tabel 6.

Biaya Overhead Pabrik

Pesanan Kain Batik Cap 100 Potong

\begin{tabular}{ccc}
\hline No & Nama Produk & Biaya Overhead Pabrik (Rp) \\
\hline 1 & Kain Batik Cap & $2.695 .000,00$ \\
\hline & Jumlah & $2.695 .000,00$ \\
\hline
\end{tabular}

(Sumber: Data Diolah)

Tabel 7

Biaya Overhead Pabrik

Pesanan Kain Batik Tulis 40 Potong

\begin{tabular}{ccc}
\hline No & Nama Produk & Biaya Overhead Pabrik (Rp) \\
\hline 1 & Kain Batik Tulis & $1.710 .000,00$ \\
\hline & Jumlah & $1.710 .000,00$ \\
\hline
\end{tabular}

(Sumber: Data Diolah) 
UD. Batik Redj'os pada bulan Mei tahun 2018 telah menyelesaikan dua produk pesanan yaitu kain batik cap sebanyak 100 potong dan kain batik tulis sebanyak 40 potong. UD. Batik Redj'os telah menetapkan persentase tingkat keuntungan sebesar 8\% dari harga pokok produksi.

\section{Perhitungan Harga Pokok Pesanan}

Perhitungan harga pokok pesanan dan harga jual dapat dilihat pada tabel berikut:

Tabel 8.

Perhitungan Harga Pokok Pesanan UD. Batik Redj'os pada Bulan Mei 2018

\begin{tabular}{lcc}
\hline \multirow{2}{*}{ Jenis Biaya } & \multicolumn{2}{c}{ Jenis Pesanan } \\
\cline { 2 - 3 } & Kain Batik Cap (Rp) & Kain Batik Tulis (Rp) \\
\hline Biaya Bahan Baku & $4.000 .000,00$ & $2.000 .000,00$ \\
\hline Biaya Tenaga Kerja Langsung & $1.965 .000,00$ & $2.085 .000,00$ \\
\hline Biaya Overhead Pabrik & $2.695 .000,00$ & $1.710 .000,00$ \\
\hline Total Biaya Produksi & $8.660 .000,00$ & $5.795 .000,00$ \\
\hline Unit Pesanan & 100 & 40 \\
\hline HPP per Unit & $86.600,00$ & $145.000,00$ \\
\hline Tingkat Keuntungan & $8 \%$ & $8 \%$ \\
\hline Laba & $692.800,00$ & $463.000,00$ \\
\hline Harga Jual & $93.500,00$ & $157.000,00$ \\
\hline (Sumber: Data Diolah) & &
\end{tabular}

Berdasarkan data tabel 8, diketahui bahwa harga pokok produk pesanan kain batik cap sebanyak 100 potong adalah Rp8.660.000,00. Artinya setiap pesanan batik cap memiliki harga pokok produk per potong sebesar Rp86.600,00 dengan persentase tingkat keuntungan sebesar $8 \%$ dari biaya produksi yang dikeluarkan untuk produk pesanannya, maka harga jual untuk pesanan 1 potong produk batik tersebut adalah Rp93.500,00 (pembulatan). Sedangkan untuk harga pokok produk pesanan kain batik tulis sebanyak 40 potong adalah sebesar Rp5.795.000,00. Artinya setiap pesanan batik tulis memiliki harga pokok per potong sebesar Rp145.000,00 dengan persentase tingkat keuntungan $8 \%$ dari biaya produksi, maka harga jual untuk per potong produk batik tulis sebesar Rp157.000,00 (pembulatan).

\section{Perhitungan Harga Pokok Pesanan dengan Metode Variable Costing}

Setelah melakukan analisis terhadap perhitungan harga pokok pesanan yang dilakukan oleh perusahaan, peneliti menemukan kejanggalan dalam perhitungan harga pokok produk pesanannya, terutama dalam pembebanan biaya overhead pabrik. UD. 
Batik Redj'os hanya memasukkan biaya bahan penolong sebagai biaya overhead pabrik dan belum memasukkan atau menghitung semua unsur biaya variabel ke dalam harga pokok produksi terutama biaya telepon dan biaya listrik. Seharusnya UD. Batik Redj'os memasukkan atau menghitung biaya telepon dan biaya listrik ke dalam biaya overhead pabrik.

\section{Biaya Listrik}

Biaya listrik ini digunakan bersama dalam pembuatan produk pesanan. Untuk mengetahui biaya listrik yang dibebankan ke masing-masing produk, peneliti menghitung harga pokok listrik untuk per unit produk. Berikut perhitungannya:

Harga pokok per unit $=\operatorname{Rp} 714,00$

Biaya listrik batik cap $=\operatorname{Rp} 714,00 \times 100=\operatorname{Rp} 71.400,00$

Biaya listrik batik tulis $=\mathrm{Rp} 714,00 \times 40=\mathrm{Rp} 28.600,00$

\section{Biaya Telepon}

UD. Batik Redj'os dalam melakukan kegiatan produksi juga mengeluarkan biaya telepon. Hal ini digunakan untuk memberikan informasi kepada konsumen atau pelanggan tentang produk yang dipesan setelah diproduksi. Selama bulan Mei UD. Batik Redj'os mengeluarkan biaya telepon sebesar Rp. 110.000. Biaya telepon ini digunakan bersama dalam pembuatan produk pesanan UD. Batik Redj'os, baik produk batik cap ataupun batik tulis. Penulis menghitung biaya telepon sebagai berikut:

Harga pokok per unit $=\mathrm{Rp} 786,00$

Biaya listrik batik cap $=\mathrm{Rp} 786,00 \times 100=\mathrm{Rp} 78.600,00$

Biaya listrik batik tulis $=\mathrm{Rp} 786,00 \times 40=\mathrm{Rp} 31.400,00$

Perhitungan biaya overhead pabrik menurut peneliti dilakukan dengan cara menentukan tarif biaya overhead pabrik yang telah ditentukan dimuka untuk setiap pesanan dengan menggunakan dasar penentuan tarif dan pembebanan tertentu. Untuk menentukan tarif biaya overhead pabrik yang ditentukan dimuka berdasarkan pembebanan biaya bahan baku dibutuhkan taksiran pemakaian bahan baku dan taksiran biaya overhead pabrik pada peroide tertentu. 


\section{Perhitungan Tarif BOP}

Berikut akan disajikan data dan perhitungan tarif biaya overhead pabrik dengan menggunakan biaya bahan baku dan biaya overhead pabrik yang digunakan pada bulan Mei 2018:

Tabel 9.

Biaya Bahan Baku

pada Bulan Mei 2018

\begin{tabular}{lccc}
\hline \multicolumn{1}{c}{ Jenis } & $\begin{array}{c}\text { Kuantitas } \\
(\text { Meter })\end{array}$ & $\begin{array}{c}\text { Harga Satuan } \\
(\mathbf{R p})\end{array}$ & $\begin{array}{c}\text { Jumlah } \\
(\mathbf{R p})\end{array}$ \\
\hline Kain Mori Jenis Prima & 200 & $20.000,00$ & $4.000 .000,00$ \\
Kain Mori (Primissima) & 40 & $25.000,00$ & $2.000 .000,00$ \\
\hline & Jumlah & & $6.000 .000,00$ \\
\hline
\end{tabular}

(Sumber: Data Diolah)

Biaya bahan baku pada tabel 9 akan dijadikan sebagai taksiran biaya bahan baku untuk produk pesanan batik. Biaya overhead pabrik pada bulan Mei 2018 dapat dilihat pada tabel berikut:

Tabel 10.

Biaya Overhead Pabrik pada Bulan Mei 2018

\begin{tabular}{cccc}
\hline Nama Produk & Keterangan & Biaya (Rp) \\
\hline \multirow{2}{*}{ Batik Cap } & Biaya Bahan Penolong & $2.695 .000,00$ \\
& Jumlah & Biaya Listrik & $71.400,00$ \\
\cline { 2 - 4 } & & Biaya Telepon & $78.600,00$ \\
\cline { 2 - 4 } & Biaya Bahan Penolong & $2.845 .000,00$ \\
\cline { 2 - 4 } & Batik Tulis & Biaya Listrik & $1.710 .000,00$ \\
& & Biaya Telepon & $28.600,00$ \\
& Jumlah & & $31.400,00$ \\
& &
\end{tabular}

(Sumber: Data Diolah)

Tabel 10 menunjukkan biaya overhead pabrik yang sesungguhnya pada bulan Mei 2018 yaitu sebesar Rp2.845.000,00 untuk produk pesanan kain batik cap dan Rp1.770.000,00 untuk produk kain batik tulis. Angka ini kemudian dijadikan peneliti sebagai taksiran biaya overhead pabrik pada bulan Mei 2018 untuk masing-masing produk pesanan. Tarif biaya overhead pabrik yang ditentukan dimuka adalah sebagai berikut:

$$
\begin{array}{ll}
\text { Tarif BOP } & =\times 100 \% \\
\text { Tarif BOP batik cap } & =\times 100 \%=71 \% \\
\text { Tarif BOP batik tulis } & =\times 100 \%=88 \%
\end{array}
$$


Tarif biaya overhead pabrik yang telah ditentukan dimuka kemudian digunakan untuk membebankan biaya overhead pabrik kepada produk yang diproduksi. Jika perusahaan menggunakan metode variable costing di dalam penentuan harga pokok produksi, produk akan dibebankan biaya overhead pabrik dengan menggunakan tarif biaya overhead pabrik variabel saja. Oleh karena itu setiap pesanan biaya overhead pabrik dapat ditentukan seperti dalam tabel berikut:

Tabel 11.

Biaya Overhead Pabrik yang Dibebankan untuk Produk Pesanan Batik

\begin{tabular}{lccc}
\hline \multicolumn{1}{c}{ Jenis Pesanan } & $\begin{array}{c}\text { Dasar Pembebanan } \\
(\mathbf{R p})\end{array}$ & $\begin{array}{c}\text { Tarif BOP } \\
(\boldsymbol{\%})\end{array}$ & $\begin{array}{c}\text { Jumlah BOP Dibebankan } \\
(\mathbf{R p})\end{array}$ \\
\hline Kain Batik Cap & $4.000 .000,00$ & 71 & $2.840 .000,00$ \\
Kain Batik Tulis & $2.000 .000,00$ & 88 & $1.760 .000,00$ \\
\hline & Jumlah & & $4.600 .000,00$ \\
\hline
\end{tabular}

(Sumber: Data Diolah)

Tabel 11 menunjukkan biaya overhead pabrik yang dibebankan untuk masingmasing pesanan adalah untuk pesanan 100 ptong kain batik cap sebesar Rp2.840.000,00 sedangkan untuk pesanan 40 potong kain batik tulis sebesar Rp1.760.000,00.

\section{Perhitungan Harga Pokok Pesanan}

Setelah mengetahui biaya overhead pabrik yang dibebankan ke masing-masing produk pesanan, maka dapat dilakukan perhitungan harga pokok produk pesanan dengan menggunakan metode variable costing sebagai berikut:

Tabel 12.

Perhitungan Harga Pokok Pesanan dengan Variable Costing pada Bulan Mei 2018

\begin{tabular}{lcc}
\hline \multicolumn{1}{c}{ Jenis Biaya } & \multicolumn{2}{c}{ Jenis Pesanan } \\
\cline { 2 - 3 } & $\begin{array}{c}\text { Kain Batik Cap } \\
(\mathbf{R p})\end{array}$ & $\begin{array}{c}\text { Kain Batik Tulis } \\
(\mathbf{R p})\end{array}$ \\
\hline Biaya Bahan Baku & $4.000 .000,00$ & $2.000 .000,00$ \\
\hline Biaya Tenaga Kerja Langsung & $1.965 .000,00$ & $2.085 .000,00$ \\
\hline Biaya Overhead Pabrik & $2.840 .000,00$ & $1.760 .000,00$ \\
\hline Total Biaya Produksi & $8.805 .000,00$ & $5.845 .000,00$ \\
\hline Unit Pesanan & 100 & 40 \\
\hline HPP per Unit & $88.050,00$ & $746.125,00$ \\
\hline Tingkat Keuntungan & $6 \%$ & $435.000,00$ \\
\hline Laba & $545.000,00$ & $157.000,00$ \\
\hline Harga Jual & $93.000,00$ &
\end{tabular}


Tabel 12 menunjukkan harga pokok produk pesanan untuk kain batik cap sebanyak 100 potong sebesar Rp8.805.000,00 dengan harga pokok per potong adalah Rp88.050,00. Harga jual yang ditentukan perusahaan sebesar Rp93.500,00 sehingga laba yang diperoleh atas pesanan tersebut adalah sebesar Rp545.000,00 dengan tingkat keuntungan $6 \%$. Sedangkan harga pokok pesanan kain batik tulis untuk pesanan 40 potong sebesar Rp5.845.000,00 dengan harga pokok per potong Rp146.125,00. Harga jual yang ditentukan perusahaan untuk kain batik tulis sebesar Rp157.000,00 sehingga laba yang diperoleh perusahaan atas pesanan batik tulis adalah sebesar Rp435.000 dengan tingkat keuntungan yang diperoleh sebesar $7 \%$.

\section{Selisih atau Perbedaan Biaya}

Pembebanan tarif biaya overhead pabrik ditentukan dimuka menimbulkan selisih atau perbedaan antara biaya overhead pabrik yang dibebankan oleh perusahaan UD. Batik Redj'os dengan biaya overhead pabrik yang dibebankan oleh peneliti dengan metode variable costing. Hal tersebut dapat terlihat pada tabel berikut:

Tabel 13.

Perbedaan BOP pada Produk Pesanan Kain Batik Cap dan Batik Tulis pada Bulan Mei 2018

\begin{tabular}{lccc}
\hline Produk Pesanan & $\begin{array}{c}\text { BOP Perusahaan } \\
(\mathbf{R p})\end{array}$ & $\begin{array}{c}\text { BOP Variable Costing } \\
(\mathbf{R p})\end{array}$ & $\begin{array}{c}\text { Selisih } \\
(\mathbf{R p})\end{array}$ \\
\hline Kain Batik Cap & $2.695 .000,00$ & $2.840 .000,00$ & $145.000,00$ \\
\hline Kain Batik Tulis & $1.710 .000,00$ & $1.760 .000,00$ & $50.000,00$ \\
\hline (Sumber: Data Diolah) & & &
\end{tabular}

Tabel 13 menunjukkan bahwa terdapat selisih pembebanan biaya overhead pabrik menurut perusahaan dengan metode variable costing. Selisih biaya overhead pabrik pesanan kain batik cap untuk 100 potong batik sebesar Rp145.000,00 sedangkan selisih biaya overhead pabrik pesanan kain batik tulis untuk 40 potong batik sebesar Rp50.000,00.

Setelah melakukan pendeskripsian dan perhitungan harga pokok produk pesanan, peneliti melakukan perhitungan kembali dan didapatkan perbedaan besarnya harga pokok produk untuk pesanan yang diteliti. Secara lengkap perbedaan tersebut dapat dilihat dalam tabel 14 . 
Tabel 14.

Perbedaan Perhitungan Harga Pokok Pesanan untuk 100 Potong Kain batik Cap

\begin{tabular}{lccc}
\hline \multicolumn{1}{c}{ Jenis Biaya } & \multicolumn{2}{c}{ Harga Pokok Pesana } \\
& Perusahaan & Hasil Analisis & \multirow{2}{*}{$\begin{array}{c}\text { Selisih } \\
\text { (Rp) }\end{array}$} \\
\cline { 2 - 3 } & $4.000 .000,00$ & $4.000 .000,00$ & - \\
\hline Biaya Bahan Baku & $1.965 .000,00$ & $1.965 .000,00$ & - \\
\hline Biaya Tenaga Kerja & $2.695 .000,00$ & $2.840 .000,00$ & $145.000,00$ \\
\hline Biaya Overhead Pabrik & $8.660 .000,00$ & $8.805 .000,00$ & $145.000,00$ \\
\hline Biaya Produksi & $86.600,00$ & $88.050,00$ & $1.450,00$ \\
\hline HPP per Unit & $93.500,00$ & $93.500,00$ & - \\
\hline Harga Jual & $692.800,00$ & $545.000,00$ & $147.800,00$ \\
\hline Laba & $8 \%$ & $6 \%$ & $2 \%$ \\
\hline Tingkat Keuntungan & & & \\
\hline
\end{tabular}

(Sumber: Data Diolah)

Berdasarkan tabel 14, dapat diketahui bahwa selisih perhitungan harga pokok produksi pesanan sebanyak 100 potong batik cap menurut perhitungan perusahaan dengan metode variable costing sebesar Rp145.000,00 dengan selisih harga pokok per produk sebesar Rp1.450,00. Hal tersebut disebabkan adanya perbedaan perhitungan pada pembebanan biaya overhead pabrik yang telah dilakukan peneliti menggunakan metode variable costing dengan perhitungan yang dilakukan perusahaan.

Tabel 15.

Perbedaan Perhitungan Harga Pokok Pesanan untuk 40 Potong Kain batik Tulis

\begin{tabular}{lccc}
\hline \multicolumn{1}{c}{ Jenis Biaya } & \multicolumn{2}{c}{ Harga Pokok Pesanan } & Selisih \\
& Perusahaan & Hasil Analisis & $($ Rp) \\
\cline { 2 - 3 } & $2.000 .000,00$ & $2.000 .000,00$ & - \\
\hline Biaya bahan baku & $2.085 .000,00$ & $2.085 .000,00$ & - \\
\hline Biaya tenaga kerja & $1.710 .000,00$ & $1.760 .000,00$ & $50.000,00$ \\
\hline Biaya overhead pabrik & $5.795 .000,00$ & $5.845 .000,00$ & $50.000,00$ \\
\hline Biaya produksi & $145.000,00$ & $146.125,00$ & $1.125,00$ \\
\hline HPP per unit & $93.500,00$ & $93.500,00$ & - \\
\hline Harga jual & $463.000,00$ & $435.000,00$ & $28.000,00$ \\
\hline Laba & $8 \%$ & $7 \%$ & $1 \%$ \\
\hline Tingkat keuntungan & & &
\end{tabular}

Berdasarkan tabel 15, dapat diketahui bahwa selisih perhitungan harga pokok produk pesanan sebanyak 40 potong batik tulis menurut perhitungan perusahaan dengan metode variable costing sebesar Rp50.000,00 dengan selisih harga pokok per produk sebesar Rp1.125,00. Hal tersebut disebabkan adanya perbedaan perhitungan pembebanan biaya overhead pabrik yang telah dilakukan peneliti menggunakan metode 
variable costing dengan perhitungan yang dilakukan perusahaan maka tingkat laba yang diperoleh lebih kecil mencapai 7\% dibandingkan dengan perhitungan perusahaan.

\section{PEMBAHASAN}

Menurut Soei et al., (2014) harga jual merupakan nominal yang harus dapat menutup semua biaya yang dikeluarkan dan menghasilkan laba yang diinginkan oleh perusahaan. Faktor biaya merupakan faktor utama dalam menentukan harga jual karena biaya menggambarkan batas minimum yang harus dipenuhi perusahaan agar tidak mengalami kerugian. Harga pokok produksi merupakan satu-satunya faktor penentu penetapan harga jual.

Mulyadi (2012) menyatakan bahwa metode penentuan harga pokok produksi adalah cara perhitungan unsur-unsur biaya ke dalam harga pokok produksi. Salah satu metode yang digunakan untuk menentukan harga pokok produksi adalah variable costing yang hanya memperhitungkan biaya produksi yang berperilaku sebagai variabel ke dalam harga pokok produksi yang terdiri dari bahan baku, biaya tenaga kerja langsung dan biaya overhead pabrik variabel. Tidak diperhitungkannya biaya overhead pabrik tetap dalam persediaan dan harga pokok persediaan akan mengakibatkan nilai persediaan lebih rendah, sehingga akan mengurangi modal kerja yang dilaporkan untuk tujuan-tujuan analisis keuangan (Uzry, 2009). Dalam memperhitungkan unsur-unsur biaya ke dalam harga pokok produksi, terdapat dua pendekatan yaitu full costing dan variable costing.

Menurut Samryn (2012) metode variable costing lebih banyak memberikan manfaat bagi keperluan internal manajemen, diantaranya adalah: a) laba periodik tidak dipengaruhi oleh tingkat persediaan; b) dengan menggunakan variable costing, biaya produksi per unit tidak mengandung biaya teta; c) biaya pabrik dan laporan laba rugi dalam bentuk variable costing lebih dekat dalam mengikuti pemikiran manajemen; d) pendekatan ini memungkinkan manajemen mengidentifikasi biaya-biaya yang dapat dan tidak dapat dikendalikan dalam jangka pendek; e) data variable costing relatif memudahkan penilaian kinerja menurut produk, wilayah, kelas pelanggan dan segmen lain dalam bisnis.

Berdasarkan hasil penelitian, harga pokok produksi pada UD. Batik Redj'os belum sesuai dengan perhitungan sistem akuntansi yang benar. Hal yang sama juga 
ditemukan oleh Ifana \& Yuliarini (2020) yang melakukan penelitian di UMKM Alpujabar. UMKM tersebut tidak melakukan pencatatan dan penyusunan laporan harga pokok produksi berdasarkan perhitungan sistem akuntansi yang benar. Perhitungan harga pokok produksi yang dilakukan UMKM ini hanya sebatas perkiraan saja. Padahal dengan menerapkan metode variable costing, informasi harga pokok produksi menjadi lebih akurat.

\section{SIMPULAN}

Perhitungan harga pokok produksi pada UD. Batik Redj'os belum sesuai dengan perhitungan harga pokok produksi yang sebenarnya menurut sistem akuntansi yang benar. Perusahaan ini hanya memasukkan biaya bahan penolong saja sebagai biaya overhead pabrik. Sedangkan biaya overhead pabrik baru bisa diketahui pada akhir bulan saat memasukkan biaya tersebut dalam harga pokok pesanan.

Dalam menentukan biaya overhead pabrik, perhitungan yang dilakukan perusahaan masih kurang tepat. Hal tersebut dikarenakan perusahaan belum menentukan tarif yang ditentukan di muka dalam pembebanan biaya overhead pabrik untuk setiap produksi pesanan yang dikerjakan. Adapun jumlah harga pokok pesanan kain batik cap ataupun kain batik tulis berdasarkan perhitungan metode variable costing lebih besar dari perhitungan perusahaan.

\section{DAFTAR PUSTAKA}

Carter, W. K. (2013). Akuntansi Biaya, Buku Satu, Edisi Keempat Belas. Jakarta: Salemba Empat

Elvania, D. I. (2017). Penentuan Harga Pokok Produksi dengan Menggunakan Metode Variable Costing Guna Penentuan Harga Jual Produk Tahu Takwa (Pada Usaha Bintang Barokah Kediri). Simki-Economic, 2(2), 1-10

Firdaus, A., \& Wasilah, A. (2012). Akuntansi Biaya. Jakarta: Salemba Empat

Ifana, N., \& Yuliarini, S. (2020). Penerapan Metode Variable Costing dalam Penetapan Harga Pokok Produksi pada Pelaku UMKM (Studi Kasus pada UMKM Alpujabar yang Tergabung dalam Rumah Batik Putat Jaya). Liability, 2(1), 2448

Mulyadi, M. (2007). Akuntansi Biaya. Yogyakarta: Sekolah Tinggi Ilmu Ekonomi YKPN

Mulyadi, M. (2009). Akuntansi Biaya, Edisi Kelima. Yogyakarta: Aditya Media

Mulyadi, M. (2012). Akuntansi Biaya, Edisi Kelima, Cetakan Kesebelas. Yogyakarta: Sekolah Tinggi Ilmu Manajemen YKPN 
Riwayadi, R. (2014). Akuntansi Biaya. Jakarta: Salemba Empat

Riwayadi, R. (2016). Akuntansi Biaya, Edisi Kedua. Jakarta: Salemba Empat

Rudjito, R. (2003). Peran Lembaga Keuangan Mikro dalam Otonomi Daerah Guna Menggerakkan Ekonomi Rakyat dan Menanggulangi Kemiskinan, Studi Kasus: Bank Rakyat Indonesia, Ekonomi Rakyat, Th. II-No.1-Maret2003. http://www.ekonomirakyat.org/edisi13/ artikel3.htm

Samryn, L. M. (2012). Akuntansi Manajemen Informasi Biaya untuk Mengendalikan Aktivitas Operasi dan Investasi. Jakarta: Kencana

Shepherd, M., \& Martin, J. (2018). Considerations When Determining Cost of Goods Sold Excludable from BEAT. Washington: The Tax Adviser

Soei, C. N., Sabijono, H., \& Runtu, T. (2014). Penentuan Harga Jual Produk dengan Menggunakan Metode Cost Plus Pricing pada UD. Sinar Sakti. Jurnal EMBA, 2(3), 208-217

Supriyono, R. A. (2013). Akuntansi Biaya Pengumpulan Biaya dan Penentuan Harga Pokok. Yogyakarta: Fakultas Ekonomi dan Bisnis UGM

Uzry, U. (2009). Akuntansi Biaya. Jakarta: Salemba Empat 